\title{
CUSTOMER PERCEIVED VALUE DAN CUSTOMER TRUST: IDENTIFIKASI KEPUASAN DAN LOYALITAS KONSUMEN GO-CAR
}

\author{
Yeri Resika \\ Program Studi Magister Manajemen, Fakultas Ekonomi, Universitas Sriwijaya \\ resikabahrinnur@gmail.com \\ Zakaria Wahab \\ Program Studi Magister Manajemen, Fakultas Ekonomi, Universitas Sriwijaya \\ zkwahab@yahoo.com \\ Muchsin Saggaf Shihab \\ Program Studi Magister Manajemen, Fakultas Ekonomi, Universitas Sriwijaya \\ muchsin.shihab@bakrie.ac.id
}

\begin{abstract}
ABSTRAK
Tujuan penelitian ini adalah untuk mengetahui pengaruh customer perceived value dan customer trust terhadap kepuasan dan loyalitas konsumen. Studi kasus pada mahasiswa Universitas Sriwijaya kampus Palembang pengguna Go-car. Data penelitian ini terdiri dari data primer dan data sekunder. Data primer diperoleh dengan menggunakan kuesioner. Sampel penelitian ini berjumlah 105 responden dengan menggunakan teknik Snowball Sampling. Data sekunder diperoleh dari berbagai sumber seperti buku, jurnal, dan publikasi terkait lainnya. Teknik analisis data yang digunakan adalah teknik analisis kuantitatif dengan menggunakan analisis jalur. Hasil penelitian ini mengungkapkan bahwa customer perceived value dan customer trust berpengaruh positif dan signifikan terhadap kepuasan konsumen, customer perceived value dan customer trust berpengaruh positif namun tidak signifikan terhadap loyalitas konsumen, kepuasan konsumen berpengaruh positif dan signifikan terhadap loyalitas konsumen, customer perceived value memiliki pengaruh tidak signifikan terhadap loyalitas konsumen melalui kepuasan konsumen, dan customer trust memiliki pengaruh signifikan terhadap loyalitas konsumen melalui kepuasan konsumen.
\end{abstract}

Kata Kunci: Customer Perceived Value, Customer Trust, Kepuasan Konsumen, Loyalitas konsumen, Go-Jek, Go-Car.

\begin{abstract}
The aims of this study was to determine the influence of customer perceived value and customer trust on customer satisfied and customer loyalty of Go-Car. Case study on collegian in University of Sriwijaya at Palembang used Go-Car. Both primary and secondary data were obtained. Primary data were obtained by distributing to the target respondents, a total sample of 105 respondents were obtained, using the Snowball Sampling. Secondary data were obtained from various sources such as books, journals, and other related publications. Data analysis technique used is quantitative analyze technique with Path Analyze. The results of this study revealed that customer perceived value and customer trust had positive and significant impact on customer satisfied, customer perceived value and customer trust had positive but not significant impact on customer loyalty, customer satisfied had positive and significant impact on customer loyalty, customer perceived value had no significant impact on customer loyalty by customer satisfied, and customer trust had significant impact on customer loyalty by customer satisfied.
\end{abstract}

Keywords: Customer Perceived Value, Customer Trust, Customer Satisfied, Customer Loyalty, Go-Jek, Go-Car. 


\section{PENDAHULUAN}

Jasa transportasi saat ini dirasa sebagai sarana yang sangat penting bagi penunjang kegiatan sehari-hari masyarakat. Jasa transportasi dipergunakan masyarakat untuk berbagai kegiatan seperti berangkat ke sekolah, bekerja, maupun aktifitas lainnya. Masalah transportasi umum di kota-kota besar saat ini sangatlah dinamik dan memerlukan solusi yang tepat. Dengan perkembangan teknologi yang semakin maju, muncul terobosan baru yang digagas oleh pengusaha-pengusaha di bidang teknologi informasi. Perusahaan ini menawarkan sebuah inovasi baru yaitu transportasi online berupa taksi online dan ojek online.

Hadirnya transportasi online merupakan salah satu solusi yang dirasa tepat, terutama dari keunggulan yang dimiliki daripada moda transportasi lain, di antaranya: harga yang murah, kemudahan dalam mengakses kendaraan, yang kemudian menghasilkan waktu yang efisien saat menembus padatnya lalu lintas di perkotaan. Pelayanan yang lebih baik bagi para konsumen akan memberikan efek yang luar biasa pada perusahaan. Aspek pelayanan bagi jasa transportasi memang masih ampuh untuk mempertahankan pelanggan maupun menarik pelanggan baru. Adanya pelayanan yang baik di dalam suatu perusahaan akan menciptakan loyalitas bagi para konsumennya (Tumini \& Pratiwi, 2016).

GO-JEK Indonesia merupakan salah satu badan usaha yang menyediakan jasa transportasi online. Seperti badan usaha pada umumnya, GO-JEK Indonesia hadir untuk mendapatkan keuntungan sekaligus memberikan pelayanan yang baik bagi konsumennya. Lewat aplikasi yang dapat digunakan pada smartphone, GO-JEK Indonesia memberikan pelayanan yang variatif untuk memanjakan para konsumennya. Adapun pelayanan yang ditawarkan GO-JEK Indonesia, antara lain mulai dari Go-Ride, Go-Food, dan Go-Car. Namun demikian, selain GO-JEK Indonesia terdapat beberapa perusahaan penyedia jasa transportasi online lain yang sudah beroperasi di kota-kota besar di Indonesia, salah satunya yang paling pesat perkembangannya dan bahkan menjadi pesaing terbesar GO-JEK Indonesia adalah GRAB. Transportasi online GRAB menawarkan pelayanan yang hampir sama dengan GO-JEK Indonesia.

Salah satu layanan GO-JEK yang paling populer adalah Go-Car. Go-Car merupakan 
taksi online andalan GO-JEK Indonesia dalam memenuhi kebutuhan taksi online. Dengan fasilitas kenyamanan seperti mobil pribadi, tentunya Go-Car dapat memberikan kesan tersendiri terhadap masyarakat. Untuk itu, peneliti perlu melakukan studi lebih lanjut untuk mengetahui kepuasan dan loyalitas pengguna Go-Car.

Penelitian ini bertujuan untuk mengetahui pengaruh customer perceived value dan customer trust terhadap kepuasan dan loyalitas konsumen setelah menggunakan GoCar.

Beberapa hasil penelitian yang mendukung penelitian ini, di antaranya: penelitian yang dilakukan oleh Semuel \& Wijaya (2009) dan Bernarto \& Patricia (2017) menjelaskan bahwa terdapat pengaruh yang signifikan dari customer perceived value terhadap kepuasan konsumen. Penelitian yang dilakukan Bernarto \& Patricia (2017) dan Semuel \& Wijaya (2009) menjelaskan bahwa customer perceived value berpengaruh signifikan terhadap loyalitas konsumen. Selanjutnya kajian mengenai customer trust dan kepuasan konsumen. Penelitian Noeraini \& Sugiyono (2016) dan Utami (2013) menemukan bahwa terdapat pengaruh positif antara customer trust terhadap kepuasan konsumen. Mengenai hubungan antara customer trust dan loyalitas konsumen, penelitian yang dilakukan oleh Vuuren, Lombard, \& Tonder (2012) dan Bahrudin \& Zuhro (2015) memberikan hasil yang berbeda dengan penelitian yang dilakukan oleh Bernarto \& Patricia (2017). Dimana hasil Vuuren, Lombard, \& Tonder (2012) dan Bahrudin \& Zuhro (2015) menunjukkan bahwa customer trust memberikan pengaruh yang signifikan terhadap loyalitas konsumen. Sedangkan hasil penelitian yang dilakukan oleh Bernarto \& Patricia (2017) menunjukkan bahwa customer trust memberikan pengaruh yang negatif terhadap loyalitas konsumen.

Eid (2011) dan Khan (2012) menemukan bahwa kepuasan konsumen berpengaruh signifikan terhadap loyalitas konsumen. Penelitian yang sama juga dilakukan oleh Siddiqi (2011) dan Semuel \& Wijaya, (2009) menemukan bahwa kepuasan konsumen berpengaruh positif terhadap loyalitas konsumen. Namun sebaliknya penelitian Dewi, Kumadji, \& Mawardi (2015) menemukan bahwa kepuasan konsumen berpengaruh tidak signifikan terhadap loyalitas konsumen. 
Penelitian Haryono (2013) menemukan bahwa kepuasan tidak berpengaruh terhadap loyalitas.

Berdasarkan latar belakang tersebut, penelitian ini bertujuan untuk mengetahui pengaruh customer perceived value dan customer trust terhadap kepuasan dan loyalitas konsumen Go-Car, serta untuk mengetahui pengaruh customer perceived value dan customer trust terhadap loyalitas melalui kepuasan konsumen Go-Car.

\section{TINJAUAN}

TEORI

DAN

\section{PENGEMBANGAN HIPOTESIS}

\section{Customer Perceived Value}

Customer value adalah pilihan yang dirasakan pelanggan dan evaluasi terhadap atribut produk dan jasa, kinerja atribut dan konsekuensi yang timbul dari penggunaan produk untuk mencapai tujuan dan maksud konsumen ketika menggunakan produk (Woodruff, 1997). Persepsi adalah proses yang digunakan oleh seorang individu untuk memilih, mengorganisasi, dan menginterpretasi masukan informasi guna menciptakan gambaran dunia yang memiliki arti (Kotler \& Keller, 2009: 228). Customer perceived value adalah sebuah trade-off antara manfaat dan pengorbanan yang dirasakan konsumen dengan interaksi antara pelanggan dan produk (Payne \& Holt, 2001).

Menurut Sweeney \& Soutar (2001), customer perceived value terdiri empat aspek utama, antara lain: (1) Emotional Value, yaitu utilitas atau manfaat yang berasal dari perasaan atau afektif atau emosi positif yang ditimbulkan dari mengkonsumsi produk. Pikiran atau perasaan pelanggan (good mood atau bad mood) dapat mempengaruhi respon pelanggan terhadap jasa. Emosi positif seperti perasaan bahagia, nyaman, senang, gembira, dan sebagainya akan meningkatkan kepuasan pelanggan (Zeithaml \& Bittner, 2003);

Social Value, yaitu manfaat yang didapatkan dari kemampuan produk untuk meningkatkan konsep diri-sosial konsumen; (3) Price/Value of Money, yakni manfaat yang didapatkan dari produk yang berkaitan dengan biaya jangka pendek dan biaya jangka panjang; (4) Quality/Performance Value, yaitu manfaat yang diperoleh dari kualitas yang dipersepsikan dan kinerja yang diharapkan dari produk.

\section{Customer Trust}

Trust adalah harapan yang dipegang/dimiliki oleh individu atau kelompok bahwa kata-kata, janji, pernyataan secara verbal atau tertulis dari orang lain atau kelompok lain 
dapat diandalkan atau dipercaya (Rotter, 1967:

651). Menurut Mayer et. al. (1995), trust adalah

kemauan seseorang untuk peka terhadap

tindakan orang lain berdasarkan pada harapan

bahwa orang lain akan melakukan tindakan

tertentu pada orang yang mempercayainya,

tanpa tergantung pada kemampuannya untuk mengawasi dan mengendalikannya.

Kepercayaan dibangun antara pihakpihak yang belum saling mengenal baik dalam interaksi maupun proses transkasi (McKnight et. al., 2002). Kepercayaan tidak begitu saja dapat diakui oleh pihak lain, melainkan harus dibangun mulai dari awal dan dapat dibuktikan. Jika seorang konsumen dapat percaya dan yakin akan suatu kinerja sebuah sistem baik, maka konsumen akan menggunakan dan menganggap sebuah sistem tersebut akan menghasilkan hasil yang positif bagi para penggunanya. McKnight et. al., (2002) menyatakan bahwa ada dua dimensi kepercayaan konsumen, yaitu:

\section{Trusting Belief}

Trusting belief adalah sejauh mana seseorang percaya dan merasa yakin terhadap orang lain dalam suatu situasi. Trusting belief adalah persepsi pihak yang percaya (konsumen) terhadap pihak yang dipercaya yang mana perusahaan memiliki karakteristik yang akan menguntungkan konsumen. Ada tiga elemen yang membangun trusting belief, antara lain: (a) Benevolence (niat baik), berarti seberapa besar seseorang percaya kepada perusahaan untuk berperilaku baik kepada konsumen. Benevolence merupakan kesediaan perusahaan untuk melayani kepentingan konsumen; (b) Integrity (integritas), adalah seberapa besar keyakinan seseorang terhadap kejujuran perusahaan untuk menjaga dan memenuhi kesepakatan yang telah dibuat kepada konsumen; (c) Competence (kompetensi), adalah keyakinan seseorang terhadap kemampuan yang dimiliki perusahaan untuk membantu konsumen dalam melakukan sesuatu sesuai dengan yang dibutuhkan konsumen tersebut. Esensi dari kompetensi adalah seberapa besar keberhasilan perusahaan untuk menghasilkan hal yang diinginkan oleh konsumen. Inti dari kompetensi adalah kemampuan perusahaan untuk memenuhi kebutuhan konsumen.

\section{Trusting Intention}

Trusting intention adalah suatu hal yang disengaja di mana seseorang siap 
bergantung pada orang lain dalam suatu situasi. Ini terjadi secara pribadi dan mengarah langsung kepada orang lain. Trusting intention didasarkan pada kepercayaan kognitif seseorang kepada orang lain. Ada dua elemen yang membangun trusting intention yaitu:

a. Willingness to depend; adalah kesediaan konsumen untuk bergantung kepada perusahaan berupa penerimaan resiko atau konsekuensi negatif yang mungkin terjadi.

b. Subjective probability of depending; adalah kesediaan konsumen secara subyektif berupa pemberian informasi pribadi kepada perusahaan, melakukan transaksi, serta bersedia untuk mengikuti saran atau permintaan dari perusahaan.

\section{Kepuasan Konsumen}

Kepuasan merupakan evaluasi konsumen secara keseluruhan setelah pembelian yaitu konsumen memberikan respon kepuasan pada saat setelah pembelian dengan cara membandingkan kinerja produk setelah pembelian dengan harapan sebelum pembelian (Fornell, 1992). Kepuasan konsumen sangat bergantung pada harapan konsumen itu sendiri.
Oleh karena itu, strategi kepuasan konsumen harus didahulukan dengan pengetahuan yang detail dan akurat terhadap harapan konsumen. Adapun dimensi kepuasan konsumen menurut Fornell (1992), antara lain: (1) Kepuasan general atau keseluruhan (overall satisfaction); (2) Konfirmasi harapan (confirmation of expectations), yakni tingkat kesesuaian antara kinerja dengan ekspektasi; (3) Perbandingan dengan situasi ideal (comparison to ideal), yaitu kinerja produk dibandingkan dengan produk ideal menurut presepsi konsumen.

Kepuasan konsumen ditentukan oleh persepsi konsumen atau performance produk/jasa dalam memenuhi harapan konsumen. Konsumen merasa puas apabila harapannya terpenuhi atau akan sangat puas jika harapan pelanggan terlampaui. Menurut Irawan (2003) faktor-faktor pendorong kepuasan konsumen yaitu: (1) Kualitas produk. pelanggan akan puas jikalau setelah membeli dan menggunakan produk tersebut ternyata kualitas produk tersebut baik; (2) Harga. Bagi pelanggan yang sensitif, biasanya harga yang murah adalah sebuah kepuasan yang penting. Terutama pada industri ritel, komponen harga dinilai sangat penting dan kontribusinya terhadap kepuasan relatif besar; (3) Kualitas 
layanan. Faktor ini sangat bergantung pada keahlian penyedia jasa layanan. Dengan adanya layanan yang baik, maka pengguna jasa akan merasa puas, dan sebaliknya; (4) Faktor emosional. Produk tertentu yang erat kaitannya dengan gaya hidup dapat menarik konsumen untuk menggunakannya; (5) Kemudahan. Untuk mendapatkan suatu produk atau jasa, pelanggan akan semakin puas apabila relatif mudah, nyaman, dan efisien dalam mendapatkannya.

\section{Loyalitas Konsumen}

Loyalitas merupakan sebuah komitmen untuk melakukan pembelian kembali dan menggunakan sebuah produk atau jasa secara konsisten di masa depan, tanpa menghiraukan pengaruh situasional dan usaha-usaha pemasaran yang berpotensi mengarahkan pelanggan untuk beralih ke produk lainnya (Oliver, 1999).

Menurut Griffin (2005), loyalitas adalah perilaku pembelian yang didefinisikan sebagai pembelian non random diungkapkan dari waktu ke waktu oleh beberapa unit pengambilan keputusan. Artinya adalah konsumen yang loyal akan selalu menggunakan suatu produk secara berulang tanpa terpengaruh oleh keadaan apapun sekalipun hal tersebut mencoba mengarahkannya untuk beralih ke produk lain.

Schiffman \& Kanuk (2007) menyatakan bahwa loyalitas merek terbagi dalam dua dimensi antara lain:

\section{Attitudinal Loyalty (pengukuran sikap)}

Attitudinal loyalty meliputi 3 bagian, yaitu:

a. Cognitive Loyalty

Loyalitas ini merupakan representasi dari apa yang dipercayai oleh pelanggan. Dimensi kognitif berisikan persepsi, kepercayaan dan stereotype seorang pelanggan mengenai suatu merek.

\section{b. Affective Loyalty}

Loyalitas ini didasarkan pada perasaan dan komitmen pelanggan terhadap suatu merek. Pelanggan memiliki kedekatan emosional terhadap merek tersebut. Loyalitas afektif ini merupakan fungsi dari perasaan dan sikap pelanggan terhadap sebuah merek seperti rasa senang, suka, dan gemar. Pengungkapan perasaaan ini dapat dengan atau tanpa membandingkan dengan merek lain. Jika pelanggan memiliki sikap yang positif terhadap merek, maka dalam diri pelanggan akan berkembang loyalitas afektif. 
c. Conative Loyalty (behavioral intent)

Loyalitas konatif merupakan batas antara attitudinal loyalty dan behavioral loyalty yang direpresentasikan melalui kecenderungan perilaku pelanggan untuk menggunakan merek yang sama di masa yang akan datang. Loyalitas konatif merupakan tingkah laku yang masih bersifat intent, belum tampak dalam tingkah laku nyata.

\section{Behavioral Loyalty (pengukuran perilaku)}

Meliputi action loyalty, yang didefinisikan sebagai tingkah laku membeli ulang suatu merek oleh seorang pelanggan terhadap kategori produk tertentu. Tingkah laku seorang pelanggan yang loyal tercermin melalui frekuensi dan konsistensi pembelian suatu merek. Selain itu, salah satu aktualisasi loyalitas pelanggan ditunjukkan oleh tindakan merekomendasikan dan mempromosikan merek tersebut kepada pihak lain.

Menurut Griffin (2005), loyalitas pelanggan memiliki beberapa indikator, antara lain: (1) Melakukan pembelian berulang secara teratur; (2) Mereferensikan kepada orang lain; dan (3) Menunjukan kekebalan terhadap tarikan dari pesaing.

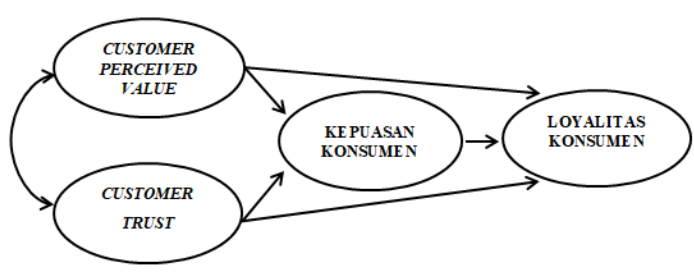

Gambar 1. Diagram Alur Pikir

\section{Penelitian}

Berdasarkan pada penjelasan di atas, maka hubungan antar variabel dalam penelitian ini dapat digambarkan dalam diagram alur pikir penelitian sebagaimana tertera pada Gambar 1.

Berdasarkan rumusan masalah yang telah dibuat, maka dirumuskan hipotesis sebagai berikut:

H1 : Customer perceived value dan customer trust berpengaruh signifikan terhadap kepuasan konsumen Go-Car

$\mathrm{H} 2$ : Customer perceived value, customer trust, dan kepuasan konsumen berpengaruh signifikan terhadap loyalitas konsumen Go-Car

H3 : Customer perceived value dan customer trust memiliki pengaruh yang signifikan terhadap loyalitas konsumen melalui kepuasan konsumen Go-Car. 
METODE RISET

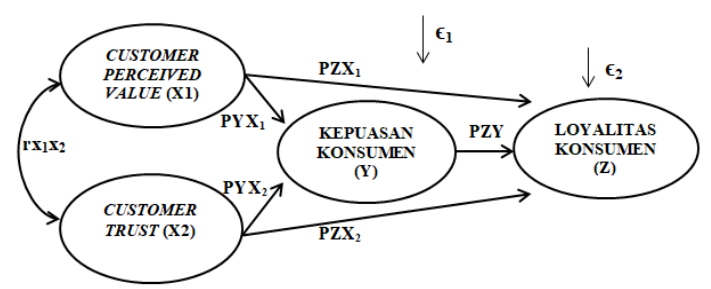

Gambar 2. Diagram analisis jalur

Keterangan:

$$
\begin{aligned}
& \mathrm{Y}=\text { Kepuasan Konsumen } \\
& \mathrm{Z}=\text { Loyalitas Konsumen } \\
& \mathrm{X}_{1}=\text { Customer Perceived Value } \\
& \mathrm{X}_{2}=\text { Customer Trust } \\
& \epsilon_{1 \& 2}=\text { Standart Error }
\end{aligned}
$$

Desain penelitian ini merupakan riset konklusif yang bersifat kausal. Riset konklusif adalah riset yang didesain untuk menolong pengambil keputusan dalam menentukan, mengevaluasi dan memilih alternatif terbaik dalam memecahkan suatu masalah (Rangkuti, 2007).

Pengumpulan data dilakukan dengan pengisian kuesioner oleh responden. Jumlah responden untuk penelitian ini adalah 105 orang. Teknik pengambilan sampel yang digunakan dalam penelitian ini adalah non probability sampling dengan metode snowball sampling.
Teknik analisis data yang digunakan pada penelitian ini adalah teknik analisis kuantitatif dengan menggunakan analisis jalur (path analyze). Adapun diagram jalur dalam penelitian ini dijelaskan pada Gambar 2 di atas. Berdasarkan diagram jalur pada Gambar 2, persamaan substruktural dari penelitian ini antara lain:

1. Persamaan substruktural 1

$$
\mathrm{Y}=\mathrm{PYX}_{1}+\mathrm{PYX} \mathrm{X}_{2}+\epsilon_{1}
$$

2. Persamaan substruktural 2

$$
Z=P Z X_{1}+P Z X_{2}+P Z Y+\epsilon_{2}
$$

\section{HASIL PENELITIAN DAN PEMBAHASAN}

\section{Deskripsi Responden Penelitian}

Jumlah sampel yang digunakan dalam penelitian ini sebanyak 105 responden, dengan kriteria jenis kelamin, asal fakultas, frekuensi penggunaan, dan sumber informasi. Karakteristik responden secara lengkap disajikan pada Tabel 1.

Hasil penelitian ini diketahui jumlah responden perempuan lebih banyak daripada jumlah responden laki-laki. Responden yang berasal dari Fakultas Keguruan dan Ilmu Pendidikan (FKIP) menduduki jumlah terbanyak. Frekuensi pemakaian terbanyak yaitu lebih dari 1 tahun dan sumber informasi responden mayoritas berasal dari teman. 
Tabel 1. Karakteristik Responden

\begin{tabular}{|c|c|c|c|}
\hline No. & Kategori & $\begin{array}{c}\text { Jumlah } \\
(\mathbf{N})\end{array}$ & Persentase \\
\hline \multirow[t]{4}{*}{1.} & Jenis Kelamin: & & \\
\hline & Laki-laki & 39 & $37,1 \%$ \\
\hline & Perempuan & 66 & $62,9 \%$ \\
\hline & & 105 & $100 \%$ \\
\hline \multirow[t]{10}{*}{2.} & Fakultas: & & \\
\hline & FKIP & 18 & $17,1 \%$ \\
\hline & FISIP & 14 & $13,3 \%$ \\
\hline & $\mathrm{FE}$ & 16 & $15,2 \%$ \\
\hline & $\mathrm{FH}$ & 10 & $9,5 \%$ \\
\hline & FP & 14 & $13,3 \%$ \\
\hline & FASILKOM & 12 & $11,4 \%$ \\
\hline & FT & 11 & $10,5 \%$ \\
\hline & FK & 10 & $9,5 \%$ \\
\hline & & 105 & $100 \%$ \\
\hline \multirow[t]{7}{*}{3.} & $\begin{array}{l}\text { Frekuensi } \\
\text { Penggunaan: }\end{array}$ & & \\
\hline & $<3$ bulan & 17 & $16,2 \%$ \\
\hline & 6 bulan & 15 & $14,3 \%$ \\
\hline & 9 bulan & 6 & $5,7 \%$ \\
\hline & 1 tahun & 31 & $29,5 \%$ \\
\hline & $>1$ tahun & 36 & $34,3 \%$ \\
\hline & & 105 & $100 \%$ \\
\hline \multirow[t]{7}{*}{4.} & $\begin{array}{l}\text { Sumber } \\
\text { informasi: }\end{array}$ & & \\
\hline & Keluarga & 13 & $12,4 \%$ \\
\hline & Teman & 57 & $54,3 \%$ \\
\hline & Media cetak & 0 & 0 \\
\hline & $\begin{array}{l}\text { Media } \\
\text { elektronil }\end{array}$ & 35 & $33,3 \%$ \\
\hline & lainnya & 0 & 0 \\
\hline & & 105 & $100 \%$ \\
\hline
\end{tabular}

Sumber : Data diolah 2018

\section{Uji Validitas dan Uji Reliabilitas}

Kuesioner diuji terlebih dahulu kepada 30 responden. Setelah dilakukan pengujian, keseluruhan item dalam penelitian ini telah valid dan reliabel.

Hasil uji validitas pada Tabel 2 dipastikan bahwa butir-butir pernyataan yang digunakan mempunyai nilai yang valid, hal ini karena nilai butir-butir pernyataan yang ditunjukkan pada kolom corrected item total
Tabel 2. Hasil Uji Validitas

\begin{tabular}{|c|c|c|c|}
\hline $\begin{array}{c}\text { Item } \\
\text { (Indikator) }\end{array}$ & R-tabel & CITC $^{*}$ & Keterangan \\
\hline CPV1 & 0,349 & 0,369 & valid \\
\hline CPV2 & 0,349 & 0,416 & valid \\
\hline CPV3 & 0,349 & 0,428 & valid \\
\hline CPV4 & 0,349 & 0,542 & valid \\
\hline CPV5 & 0,349 & 0,385 & valid \\
\hline CPV6 & 0,349 & 0,396 & valid \\
\hline CPV7 & 0,349 & 0,600 & valid \\
\hline CPV8 & 0,349 & 0,579 & valid \\
\hline CT1 & 0,349 & 0,370 & valid \\
\hline CT2 & 0,349 & 0,453 & valid \\
\hline CT3 & 0,349 & 0,449 & valid \\
\hline CT4 & 0,349 & 0,398 & valid \\
\hline CT5 & 0,349 & 0,550 & valid \\
\hline CS1 & 0,349 & 0,564 & valid \\
\hline CS2 & 0,349 & 0,588 & valid \\
\hline CS3 & 0,349 & 0,621 & valid \\
\hline CS4 & 0,349 & 0,506 & valid \\
\hline CS5 & 0,349 & 0,534 & valid \\
\hline CL1 & 0,349 & 0,377 & valid \\
\hline CL2 & 0,349 & 0,507 & valid \\
\hline CL3 & 0,349 & 0,560 & valid \\
\hline
\end{tabular}

*) Corrected Item-Total Correlation Sumber: Data diolah 2018

correlation (CITC) memiliki nilai lebih besar dari $r$ tabel $(0,349)$.

Pada tabel 3 diketahui bahwa nilai Cronbach's Alpha untuk variabel customer perceived value $\left(\mathrm{X}_{1}\right)$, customer trust $\left(\mathrm{X}_{2}\right)$, kepuasan konsumen (Y) dan loyalitas konsumen $(\mathrm{Z})$ berada di atas 0,6 sehingga dapat disimpulkan bahwa item-item kuesioner dapat dikatakan reliabel atau terpercaya sebagai alat pengumpul data dalam penelitian. 
Tabel 3. Hasil Uji Reliabilitas

\begin{tabular}{|l|c|c|c|}
\hline Variabel & $\begin{array}{c}\text { Cronbach } \\
\boldsymbol{s} \\
\text { Alpha }\end{array}$ & $\begin{array}{c}\text { Cronbach } \\
\boldsymbol{s} \\
\text { Alpha } \\
\text { Standard }\end{array}$ & Hasil \\
\hline $\begin{array}{l}\text { Customer } \\
\text { Perceived } \\
\text { Value } \\
\text { (X1) }\end{array}$ & 0.858 & 0.6 & $\begin{array}{c}\text { Reliabe } \\
1\end{array}$ \\
\hline $\begin{array}{l}\text { Customer } \\
\text { Trust } \\
\text { (X2) }\end{array}$ & 0.874 & 0.6 & $\begin{array}{c}\text { Reliabe } \\
1\end{array}$ \\
\hline $\begin{array}{l}\text { Kepuasan } \\
\text { Konsume } \\
\mathrm{n}(\mathrm{Y})\end{array}$ & 0.866 & 0.6 & $\begin{array}{c}\text { Reliabe } \\
1\end{array}$ \\
\hline $\begin{array}{l}\text { Loyalitas } \\
\text { Konsume } \\
\mathrm{n}(\mathrm{Z})\end{array}$ & 0.867 & 0.6 & $\begin{array}{c}\text { Reliabe } \\
1\end{array}$ \\
\hline
\end{tabular}

Sumber: Data diolah 2018

\section{Analisis Deskripsi Variabel Penelitian}

Pengujian hipotesis menggunakan analisis jalur. Tabel 4 menunjukkan hasil perhitungan rata-rata (mean) indikator untuk masing-masing variabel.

Melalui tabel 4 diketahui bahwa indikator Menghemat waktu mendapatkan nilai rata-rata tertinggi ada pada variabel customer perceived value yaitu 3,93. Pada variabel customer trust, nilai rata-rata tertinggi ada pada indikator niat baik dan integritas. Indikator Kualitas produk pada variabel kepuasan kosnsumen mendapat nilai rata-rata tertinggi yaitu 4,04. Pada variabel loyalitas konsumen, nilai rata-rata tertinggi terdapat pada indikator Melakukan pembelian berulang secara teratur.
Tabel 4. Rata-rata Indikator

\begin{tabular}{|c|c|c|c|}
\hline \multirow[b]{2}{*}{ Variabel } & \multirow[b]{2}{*}{ Kode } & \multicolumn{2}{|c|}{ Nilai Rata-Rata } \\
\hline & & Indikator & $\begin{array}{c}\text { Grand } \\
\text { Mean } \\
\text { Variabel }\end{array}$ \\
\hline \multirow{8}{*}{$\begin{array}{c}\text { Customer } \\
\text { Perceived } \\
\text { Value }\end{array}$} & CPV1 & 3,88 & \multirow{8}{*}{3.72} \\
\hline & CPV2 & 3,98 & \\
\hline & CPV3 & 3,2 & \\
\hline & CPV4 & 2,99 & \\
\hline & CPV5 & 3,94 & \\
\hline & CPV6 & 3,96 & \\
\hline & CPV7 & 3,73 & \\
\hline & CPV8 & 4,14 & \\
\hline \multirow{5}{*}{$\begin{array}{c}\text { Customer } \\
\text { Trust }\end{array}$} & CT1 & 3,96 & \multirow{5}{*}{3,89} \\
\hline & CT2 & 3,96 & \\
\hline & CT3 & 3,9 & \\
\hline & CT4 & 3,76 & \\
\hline & CT5 & 3,89 & \\
\hline \multirow{5}{*}{$\begin{array}{c}\text { Kepuasan } \\
\text { Konsume } \\
\text { n }\end{array}$} & CS1 & 4,04 & \multirow{5}{*}{3,93} \\
\hline & $\mathrm{CS} 2$ & 3,93 & \\
\hline & CS3 & 3,89 & \\
\hline & CS4 & 3,87 & \\
\hline & CS5 & 3,94 & \\
\hline \multirow{3}{*}{$\begin{array}{c}\text { Loyalitas } \\
\text { Konsume } \\
\text { n }\end{array}$} & CL1 & 3,85 & \multirow{3}{*}{3,65} \\
\hline & CL2 & 3,35 & \\
\hline & CL3 & 3,77 & \\
\hline
\end{tabular}

Sumber: Data diolah 2018

\section{Hasil Uji Asumsi Klasik}

Uji Normalitas

Pengujian normalitas dilakukan terhadap residual regresi. Pengujian dilakukan dengan menggunakan grafik P-P Plot. Data yang normal adalah data yang membentuk titik-titik yang menyebar tidak jauh dari garis diagonal. Hasil analisis regresi linier dengan grafik normal P-P Plot terhadap residual error model regresi yang diperoleh sudah menunjukkan adanya pola grafik yang normal, yaitu adanya sebaran titik yang berbeda tidak jauh dari garis 


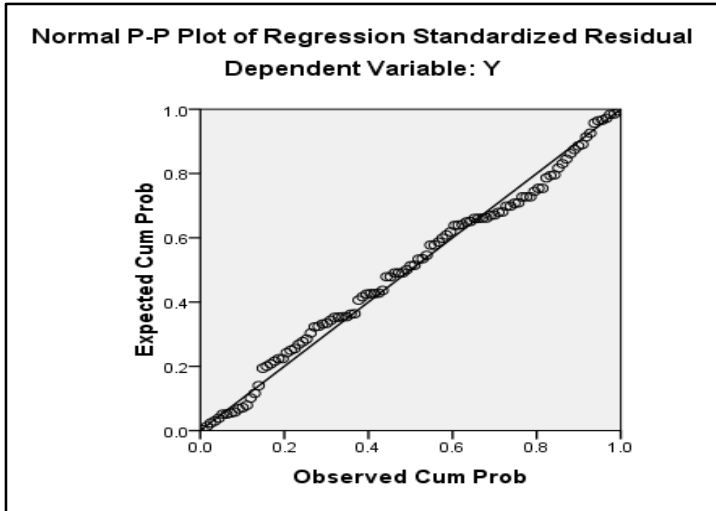

Gambar 3. Hasil Pengujian Normalitas Model 1

Sumber : Data diolah 2018

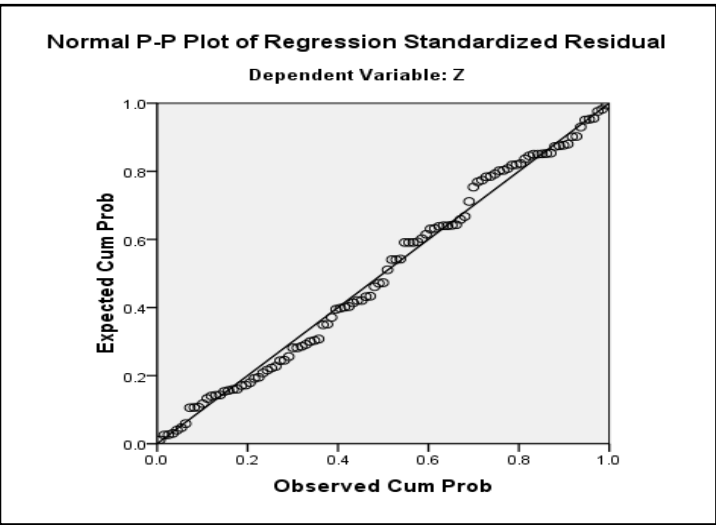

Gambar 4 Hasil Pengujian Normalitas

Model 2

Sumber : Data diolah 2018

diagonal, seperti yang ditunjukan pada Gambar 3 dan Gambar 4.

Hasil uji normalitas pada model 1 dan 2 tersebut menunjukkan bahwa titik-titik berada tidak jauh dari garis diagonal. Hal tersebut menunjukkan bahwa model regresi tersebut sudah berdistribusi secara normal.

\section{Uji Heteroskedastisitas}

Pengujian heteroskedastisitas dilakukan dengan menggunakan Scatter Plot sebagaimana terlihat pada Gambar 5 dan Gambar 6.

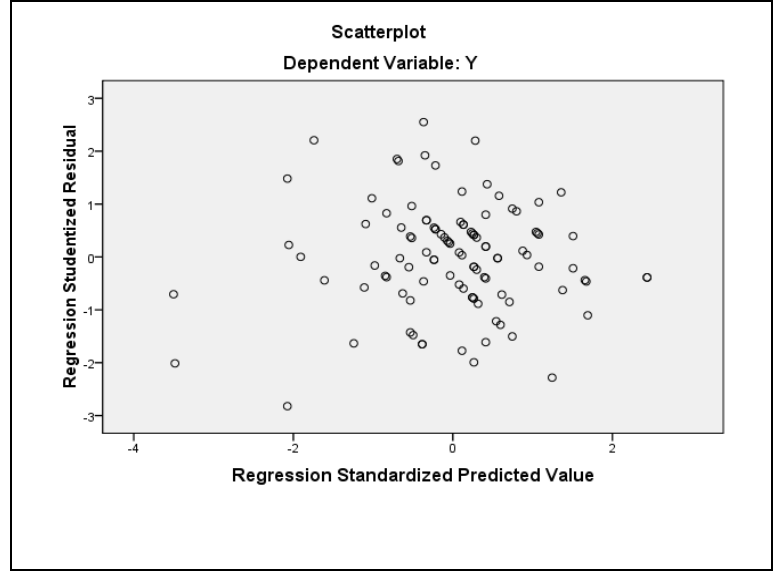

Gambar 5 Uji Heteroskedastisitas Model 1 Sumber: Data diolah 2018

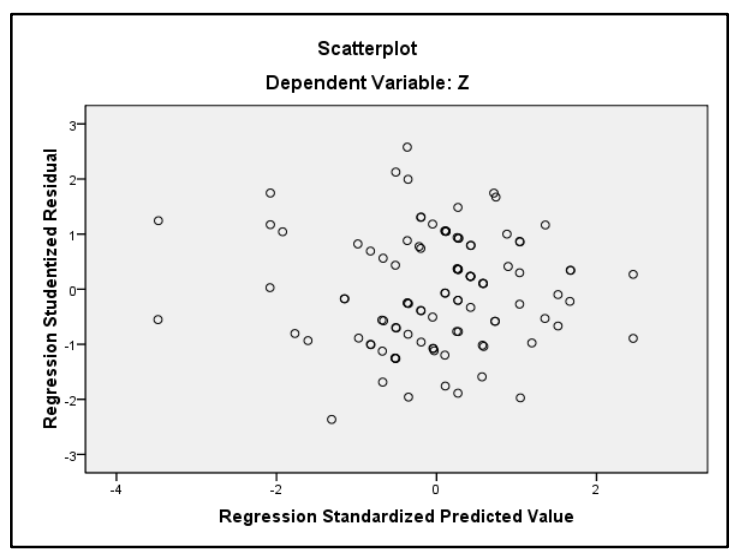

Gambar 6 Uji Heteroskedastisitas Model 2 Sumber: Data diolah 2018

Dapat dilihat pada Gambar 5 dan Gambar 6 hasil pengujian heteroskedastisitas menunjukkan bahwa titik-titik menyebar di atas angka 0 (nol) dan di bawah angka 0 (nol). Hal ini dapat disimpulkan bahwa data pada regresi jalur model 1 dan model 2 tidak mengalami masalah heteroskedastisitas atau data telah bersifat homoskedastisitas. 


\section{Hasil Uji Hipotesis}

Analisis Jalur (Path Analyze)

Tabel 5. Hasil Analisis Jalur

\begin{tabular}{|c|c|c|c|c|}
\hline \begin{tabular}{|l|} 
Variabe \\
Eksogen
\end{tabular} & \begin{tabular}{|l} 
Variabel \\
Endogen
\end{tabular} & $\beta$ & Sig. & Ket. \\
\hline $\mathrm{X} 1$ & \multirow{2}{*}{ Y } & 0,488 & 0,000 & Sig. \\
\hline $\mathrm{X} 2$ & & 0,413 & 0,004 & Sig. \\
\hline X1 & \multirow{3}{*}{ Z } & 0,220 & 0,072 & $\begin{array}{l}\text { Tdk } \\
\text { Sig. }\end{array}$ \\
\hline $\mathrm{X} 2$ & & 0,141 & 0,227 & $\begin{array}{l}\text { Tdk } \\
\text { Sig. }\end{array}$ \\
\hline $\mathrm{Y}$ & & 0,363 & 0,007 & Sig. \\
\hline
\end{tabular}

Sumber: Data diolah 2018

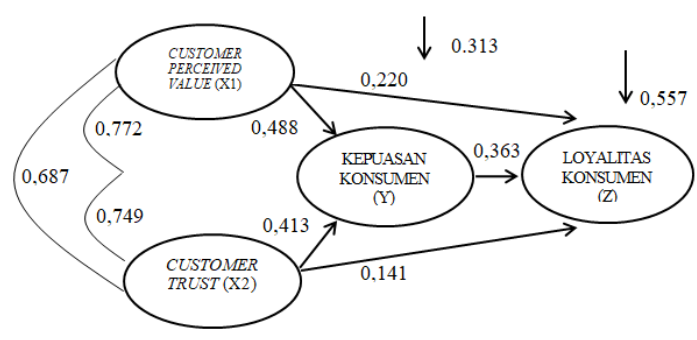

Gambar 7. Diagram Koefisien Regresi

Persamaan struktural yang terdapat pada

Tabel 5 adalah berikut ini:

1. Persamaan substruktural 1

$\mathrm{Y}=0.488 \mathrm{X}_{1}+0.413 \mathrm{X}_{2}+0,313$

2. Persamaan substruktural 2

$Z=0,220 X_{1}+0,141 X_{2}+0,363 Y+0,557$

Dari kedua persamaan struktural di atas dapat dibentuk diagram koefisien regresi sebagaimana tertera dalam gambar 7 .

Pengaruh Langsung, Tidak Langsung, dan Pengaruh Total

Berikut adalah rangkuman hasil perhitungan pengaruh pada analisis jalur model
Tabel 6. Pengaruh Langsung, Tidak Langsung dan Pengaruh Total

\begin{tabular}{|c|c|c|c|c|c|}
\hline \multirow{2}{*}{$\begin{array}{c}\text { Jalur } \\
\text { Model }\end{array}$} & \multirow{2}{*}{$\begin{array}{c}\text { Pengaruh } \\
\text { Variabel }\end{array}$} & \multicolumn{2}{|c|}{ Pengaruh } & \multirow[b]{2}{*}{ Sisa } & \multirow[b]{2}{*}{ Total } \\
\hline & & Langsung & $\begin{array}{c}\text { Tidak } \\
\text { Langsung }\end{array}$ & & \\
\hline \multirow{3}{*}{1} & $\begin{array}{l}\mathrm{X} 1 \rightarrow \\
\mathrm{Y}\end{array}$ & 0.488 & & & $\begin{array}{c}0.48 \\
8\end{array}$ \\
\hline & $\begin{array}{l}\mathrm{X} 2 \rightarrow \\
\mathrm{Y}\end{array}$ & 0.413 & & & $\begin{array}{c}0.41 \\
3\end{array}$ \\
\hline & $\begin{array}{l}\mathrm{X} 1, \mathrm{X} 2 \\
\rightarrow \mathrm{Y}\end{array}$ & 0,687 & & $\begin{array}{c}0.31 \\
3\end{array}$ & $\begin{array}{c}1.00 \\
0\end{array}$ \\
\hline \multirow{4}{*}{2} & $\mathrm{X} 1 \rightarrow \mathrm{Z}$ & 0,220 & 0,177 & & $\begin{array}{c}0.39 \\
7\end{array}$ \\
\hline & $\mathrm{X} 2 \rightarrow \mathrm{Z}$ & 0,141 & 0,149 & & $\begin{array}{c}0.29 \\
0\end{array}$ \\
\hline & $\mathrm{Y} \rightarrow \mathrm{Z}$ & 0,363 & & & $\begin{array}{c}0,36 \\
3\end{array}$ \\
\hline & $\begin{array}{l}\mathrm{X} 1, \mathrm{X} 2, \\
\mathrm{Y} \rightarrow \mathrm{Z}\end{array}$ & 0.443 & & $\begin{array}{c}0.55 \\
7\end{array}$ & $\begin{array}{c}1.00 \\
0\end{array}$ \\
\hline
\end{tabular}

Sumber: Data diolah 2018

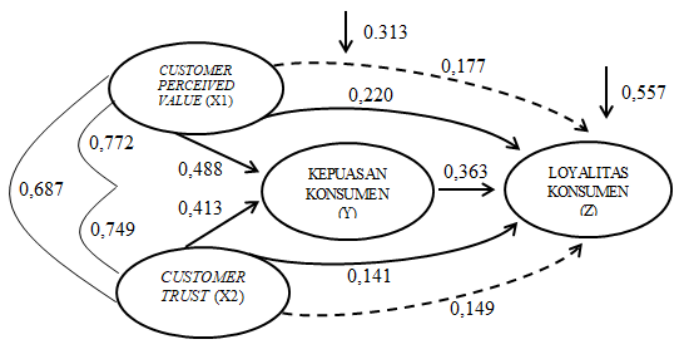

Gambar 8. Kausal empiris antar jalur model 1 dan model 2

Keterangan:

$$
\begin{aligned}
& \longrightarrow=\text { Pengaruh langsung } \\
& --\rightarrow=\text { Pengaruh tidak langsung } \\
& -=\text { Korelasi }
\end{aligned}
$$

1 dan jalur model 2 seperti terlihat pada Tabel

6 pengaruh langsung, tidak langsung dan pengaruh total.

Berdasarkan Tabel 6, dapat dibuat diagram gabungan pengaruh langsung dan tidak langsung, seperti tertera pada Gambar 4. 


\section{Pembahasan Penelitian}

Berdasarkan hasil penelitian menggunakan analisis jalur di atas maka diperoleh pembahasan hasil penelitian sebagai berikut:

\section{Pengaruh Customer Perceived Value}

\section{Terhadap Kepuasan Konsumen}

Pada jalur model 1, menunjukkan bahwa customer perceived value berpengaruh positif dan signifikan terhadap kepuasan konsumen, hal tersebut sesuai dengan penelitian yang dilakukan oleh Yang \& Peterson (2004) dan Semuel \& Wijaya (2009) bahwa terdapat pengaruh langsung positif dan signifikan antara customer perceived value terhadap kepuasan konsumen. Hal ini menunjukkan bahwa perceived value merupakan pendorong kepuasan konsumen dalam memakai Go-Car, dihubungkan dengan dimensi emotional value, social value, value of money, dan performance value. Di lihat dari hasil penelitian, indikatorindikator dimensi value of money memiliki skor rata-rata tertinggi dengan kepuasan konsumen. Mengingat harga merupakan salah satu faktor utama dalam konsumen menentukan keputusannya, untuk itu Go-Car perlu memberikan tarif yang bersaing dengan kompetitornya untuk membentuk persepsi nilai yang baik terhadap Go-Car.

Pengaruh Customer Trust Terhadap Kepuasan

\section{Konsumen}

Analisis selanjutnya menunjukkan bahwa customer trust memiliki pengaruh positif dan signifikan terhadap kepuasan konsumen. Hasil ini sejalan dengan penelitian sebelumnya yang dilakukan oleh Utami (2013) di mana customer trust secara parsial berpengaruh positif dan signifikan terhadap kepuasan konsumen. Hal ini berarti bahwa konsumen Go-Car tidak ragu untuk mempercayakan Go-Car dalam memenuhi kebutuhan transportasi, dihubungkan dengan dimensi trusting beliefe dan trusting intention. Dapat dilihat dari hasil penelitian bahwa indikator-indikator dari dimensi trusting belief (percaya dan yakin) memiliki skor rata-rata paling tinggi terhadap kepuasan konsumen. Kepercayaan merupakan elemen yang penting karena merupakan dasar dari hubungan kerjasama di kemudian hari, dengan demikian Go-Car harus terus menjaga kepercayaan konsumen dengan meningkatkan pelayanan dan keamanan dalam setiap transaksi. 
Pengaruh Customer Perceived Value Dan

Customer Trust Terhadap Kepuasan Konsumen

Customer perceived value dan customer trust memiliki pengaruh secara simultan atau berpengaruh secara bersamaan terhadap kepuasan konsumen. Customer perceived value dan customer trust juga memiliki korelasi yang positif dan signifikan, ini menunjukkan bahwa hubungan antara variabel customer perceived value dan customer trust kuat dan searah. Variabel yang dominan berpengaruh terhadap kepuasan konsumen adalah variabel customer perceived value.

\section{Pengaruh Customer Perceived Value Terhadap} Loyalitas Konsumen

Pada jalur model 2, dapat diketahui bahwa variabel customer perceived value berpengaruh positif namun tidak signifikan terhadap loyalitas konsumen. Hasil demikian berbeda dengan hasil penelitian yang dilakukan oleh Rasheed \& Abadi (2014) dan Chen \& Hu (2010) bahwa customer perceived value memiliki pengaruh yang signifikan terhadap loyalitas konsumen. Perceived value bukan merupakan faktor yang signifikan dalam menentukan loyalitas konsumen Go-Car, ini menunjukkan bahwa konsumen belum menemukan manfaat dari nilai-nilai yang diberikan oleh Go-Car. Selain biaya yang lebih tinggi dibandingkan transportasi roda dua, untuk jumlah penggunaan pribadi, mayoritas mahasiswa cukup menggunakan sepeda motor atau jalan kaki apabilah jarak masih tergolong dekat.

Pengaruh Customer Trust Terhadap Loyalitas Konsumen

Hasil analisis menunjukkan bahwa customer trust berpengaruh positif namun tidak signifikan terhadap loyalitas konsumen. Hasil ini berbeda dengan penelitian yang dilakukan oleh penelitian Rasheed \& Abadi (2014), Akbar \& Parvez (2009), dan Vuuren et al. (2012) yang menunjukkan bahwa terdapat pengaruh signifikan antara customer trust terhadap loyalitas konsumen. Customer trust bukan merupakan faktor yang signifikan dalam membentuk loyalitas konsumen secara langsung. Hal demikian bisa jadi disebabkan karena kebutuhan transportasi roda empat di kalangan mahasiswa masih belum menjadi penunjang utama untuk digunakan dalam kegiatan sehari-hari. Go-Car biasanya memuat lebih dari 2 penumpang dalam 1 mobil, untuk itu bagi kalangan mahasiswa tentu kurang 
efektif apabila hanya dipakai untuk seorang diri. Dengan adanya ruangan yang lebih luas yang terdapat dalam mobil dapat memberikan kesan kurang nyaman karena hanya ditempati satu penumpang.

\section{Pengaruh Kepuasan Konsumen Terhadap}

\section{Loyalitas Konsumen}

Hasil analisis kepuasan konsumen berpengaruh positif dan signifikan terhadap loyalitas konsumen. Ini menunjukkan bahwa indikator pembentuk kepuasan konsumen secara keseluruhan dapat menciptakan loyalitas konsumen. Hasil tersebut sama dengan hasil penelitian yang dilakukan oleh Khan (2012), Akbar \& Parvez (2009), dan Vuuren et al. (2012) bahwa kepuasan konsumen berpengaruh positif dan signifikan terhadap loyalitas konsumen. Hal ini menunjukkan bahwa kepuasan konsumen menjadi faktor penentu loyalitas konsumen dibanding variabel $\mathrm{X}_{1}$ dan $\mathrm{X}_{2}$. Dimensi yang memiliki skor rata-rata yang paling tinggi ditunjukkan oleh indikatorindikator dari dimensi overall satisfaction (kepuasan keseluruhan), artinya jika Go-Car menginginkan konsumen mereka puas dan berharap setia, harus memperhatikan kualitas produk dalam hal ini adalah kualitas aplikasi serta kualitas pelayanan mitra Go-Car. Hasil penelitian selanjutnya menunjukkan bahwa customer perceived value, customer trust, dan kepuasan konsumen memiliki pengaruh secara simultan atau berpengaruh secara bersamaan terhadap loyalitas konsumen. Customer perceived value, customer trust, dan kepuasan konsumen juga memiliki korelasi yang positif dan signifikan. Hal ini berarti bahwa hubungan antara variabel customer perceived value, customer trust, dan kepuasan konsumen kuat dan searah dalam membentuk loyalitas konsumen secara bersama-sama.

Pengaruh Customer Perceived Value Terhadap

Loyalitas Melalui Kepuasan Konsumen

Dari hasil analisis diketahui bahwa kepuasan konsumen dalam penelitian ini bukan merupakan variabel intervening antara customer perceived value dan loyalitas konsumen. Hasil demikian bententangan dengan penelitian yang dilakukan oleh Semuel \& Wijaya (2009) dan Mardikawati \& Farida (2013) bahwa customer perceived value memiliki pengaruh signifikan terhadap loyalitas melalui kepuasan konsumen. Temuan ini mengindikasikan bahwa program kepuasan konsumen belum mampu memberikan nilai 
lebih terhadap konsumen untuk menjadi loyal terhadap Go-Car.

Selanjutnya, hasil analisis menunjukkan bahwa pemilihan variabel kepuasan konsumen sebagai variabel intervening sudah tepat. Hal ini sejalan dengan penelitian yang dilakukan oleh Tatuil (2013) bahwa customer trust memiliki pengaruh terhadap loyalitas melalui kepuasan konsumen. Dari kepuasan konsumen inilah secara tidak langsung customer trust sangat efektif mempengaruhi loyalitas konsumen.

\section{KESIMPULAN DAN SARAN}

\section{Kesimpulan}

Kesimpulan dari hasil penelitian ini adalah:

1. Customer perceived value berpengaruh positif dan signifikan terhadap kepuasan konsumen Go-Car, artinya semakin tinggi persepsi nilai yang dirasakan konsumen maka tingkat kepuasan juga akan semakin meningkat.

2. Customer trust berpengaruh positif dan signifikan terhadap kepuasan konsumen GoCar, ini dimaksud bahwa semakin tinggi kepercayaan konsumen terhadap Go-Car maka tingkat kepuasan konsumen pun akan semakin meningkat. Hal tersebut berarti bahwa indikator-indikator pembentuk customer trust seperti niat baik, integritas, kompetensi, kesediaan konsumen untuk bergantung dan memberikan informasi kepada perusahaan mampu mendorong kepuasan konsumen.

3. Customer perceived value berpengaruh positif namun tidak signifikan terhadap loyalitas konsumen, hasil tersebut menunjukkan bahwa indikator-indikator variabel customer perceived value belum secara maksimal menciptakan loyalitas konsumen. Untuk itu Go-Car perlu membuat suatu strategi yang dapat digunakan untuk meningkatkan nilai pada produk yang ditawarkan. Selain itu juga perlu mengetahui nilai yang sebenarnya yang diinginkan konsumen. Bila persepsi konsumen baik akan suatu produk dapat tercipta maka itu akan menjadi aset yang tak ternilai harganya. Karena orang akan cenderung menempatkan produk dalam persepsinya lebih bernilai dari produk lain. Sehingga pada saat membutuhkan akan memilih produk tersebut sebagai pilihan.

4. Customer trust berpengaruh positif namun tidak signifikan terhadap loyalitas konsumen. Hasil tersebut menunjukkan 
bahwa indikator-indikator variabel

customer trust memiliki kemampuan yang

lemah dalam menciptakan loyalitas

konsumen. Hal tersebut menunjukkan

bahwa customer trust merupakan factor

yang penting yang perlu mendapatkan

perhatian karena terkait langsung dengan

kepuasan konsumen. Kualitas pelayanan

perlu di tingkatkan demi meraih

kepercayaan konsumen.

5. Kepuasan konsumen berpengaruh signifikan terhadap loyalitas konsumen GoCar, hal tersebut menunjukkan bahwa indikator pembentuk kepuasan konsumen seperti kualitas produk, kualitas layanan, faktor emosional, harga dan kemudahan yang ditawarkan Go-Car secara keseluruhan dapat menciptakan loyalitas konsumen.

6. Customer perceived value memiliki pengaruh tidak signifikan terhadap loyalitas konsumen melalui kepuasan konsumen. Hal ini menjelaskan bahwa kepuasan konsumen belum mampu memberikan nilai lebih terhadap konsumen untuk menjadi loyal terhadap Go-Car. Ini membuktikan bahwa kepuasan konsumen dalam penelitian ini bukan merupakan variabel intervening.
7. Customer trust memiliki pengaruh signifikan terhadap loyalitas konsumen melalui kepuasan konsumen. Hasil ini menjelaskan bahwa kepuasan konsumen dalam penelitian ini merupakan variabel intervening.

\section{Saran}

Berdasarkan kesimpulan di atas, maka perlu dilakukan penyempurnaan terhadap penelitian yang dilakukan. Adapun saran untuk peneliti selanjutnya adalah sebagai berikut:

1. Karena variabel customer perceived value dengan indikator meningkatkan prestige dan memiliki rasa bangga $\left(\mathrm{X}_{1}\right)$, variabel customer trust dengan indikator konsumen dapat mentoleransi kekurangan Go-Car $\left(\mathrm{X}_{2}\right)$, variabel kepuasan konsumen dengan indikator tarif Go-Car sudah ideal (Y), variabel loyalitas konsumen dengan indikator tidak akan menggunakan taksi online selain Go-Car (Z) mempunyai nilai di bawah rata-rata. Jadi, agar konsumen puas menggunakan Go-Car, sebaiknya Go-Car memberikan nilai tambah melalui pelayanan mitra Go-Car yaitu dengan menyediakan minuman atau makanan kecil bagi penumpang, membukakan pintu saat penumpang ingin masuk dan keluar dari 
mobil, membantu mengangkatkan barangbarang konsumen ke dalam mobil, bersikap ramah kepada konsumen, memberikan informasi mengenai keamanan dalam pengelolaan data pribadi konsumen. Dari segi harga, perusahaan perlu memberikan promo atau diskon harga yang menarik dibandingkan pesaingnya. Go-Car juga perlu mencari cara dalam mempertahankan dan meraih loyalitas penggunanya dengan merealisasikan program-program yang membuat kepuasan pelanggan semakin meningkat. Selain itu Go-Car juga perlu meningkatkan pemanfaatan teknologi informasi melalui pembaruan atau inovasi aplikasi yang lebih responsive.

2. Penelitian selanjutnya diharapkan dapat menggunakan dimensi menurut para ahli lainnya sehingga nantinya bisa diketahui dimensi apa saja yang berpengaruh secara maksimal terhadap kepuasan dan loyalitas konsumen. Selain itu, penelitian selanjutnya pun diharapkan dapat menggunakan objek penelitian yang berbeda dengan ruang lingkup populasi yang lebih luas dan sampel yang lebih banyak agar dapat memberikan hasil yang lebih baik. 


\section{DAFTAR PUSTAKA}

Akbar, M. M., \& Parvez, N. (2009). Impact Of Service Quality, Trust, And Customer Satisfaction On Customer Loyalty. ABAC Journal, 29(1), 24-38.

Bahrudin, M., \& Zuhro, S. (2015). Pengaruh Kepercayaan Dan Kepuasan Pelanggan Terhadap Loyalitas Pelanggan. Jurnal Bisnis, 3 No. 1.

Bernarto, I., \& Patricia. (2017). Pengaruh Perceived Value, Customer Satisfaction Dan Trust Terhadap Customer Loyalty Restoran XYZ Di Tangerang. Journal For Business And Entrepreneur, 1 No. 1.

Chen, P. T., \& Hu, H. H. (2010). The Effect Of Relational Benefits On Perceived Value In Relation To Customer Loyalty: An Empirical Study In The Australian Coffee Outlets Industry. International Journal Of Hospitality Management, 29(3), 405-412. Https://Doi.Org/10.1016/J.Ijhm.2009.09.006

Dewi, R. K., Kumadji, S., \& Mawardi, M. K. (2015). Pengaruh Experiential Marketing Terhadap Kepuasan Pelanggan Dan Dampaknya Pada Loyalitas Pelanggan (Survei Pada Pelanggan Tempat Wisata Jawa Timur Park 1 Kota Wisata Batu). Jurnal Administrasi Bisnis, 28(1), $1-6$.

Eid, M. I. (2011). Determinants Of E-Commerce Customer Satisfaction, Trust, And Loyalty In Saudi Arabia. Journal of Electronic Commerce Research, 12(1), 78-93. Https://Doi.Org/10.1017/CBO9781107415324.004

Fornell, C. (1992). A National Customer Satisfaction Barome- Ter: The Swedish Experience. Journal Of Marketing, 56(1), 6-21. Https://Doi.Org/10.2307/1252129

Griffin, J. (2005). Customer Loyalty: Menumbukan Dan Mempertahankan Kesetiaan Pelanggan. (D. K. Yahya, Ed.). Jakarta: Erlangga.

Haryono, R. (2013). Analisis Pengaruh Servqual, Kepuasan Dan Kepercayaan Terhadap Loyalitas Nasabah Penguna Layanan Internet Banking Dengan Menggunakan Metode Structural Equation Modelling (Studi Kasus : Bank "X”). JURNAL SAINS DAN SENI POMITS, 2 No.2, D153-D158.

Irawan, H. (2003). 10 Prinsip Kepuasan Pelanggan. Jakarta: Elex Media Komputindo.

Khan, I. (2012). Impact Of Customers Satisfaction And Customers Retention On Customer Loyalty. International Journal Of Scientific \& Technology Research, 1(2), 106-110.

Kotler, P., \& Keller, K. L. (2009). Manajemen Pemasaran. (J. Purba, Ed.) (12 Jilid 1). Jakarta: Indeks.

Mardikawati, W., \& Farida, N. (2013). Pengaruh Nilai Pelanggan Dan Kualitas Layanan Terhadap Loyalitas Pelanggan, Melalui Kepuasan Pelanggan Pada Pelanggan Bus Efisiensi (Studi Po Efisiensi Jurusan Yogyakarta-Cilacap). Jurnal Administrasi Bisnis, 2 No. 1.

Mayer, R. C., Davis, J. H., \& Schoorman, F. D. (1995). An Integrative Model Of Organizational Trust. Academy Of Management Review, 20(3), 709-734. Https://Doi.Org/10.5465/AMR.1995.9508080335

Mcknight, D. H., Choudhury, V., \& Kacmar, C. (2002). Developing And Validating Trust Measures For E-Commerce: An Integrative Typology. Information Systems Research, 
13(3), 334-359. Https://Doi.Org/10.1287/Isre.13.3.334.81

Noeraini, I. A., \& Sugiyono. (2016). Pengaruh Tingkat Kepercayaan, Kualitas Pelayanan, Dan Harga Terhadap Kepuasan Pelanggan Jne Surabaya. Jurnal Ilmu Dan Riset Manajemen, 5 No. 5, 1-17.

Oliver, R. L. (1999). Whence Consumer Loyalty? Journal Of Marketing, 63, 33. Https://Doi.Org/10.2307/1252099

Payne, A., \& Holt, S. (2001). Diagnosing Customer Value: Integrating The Value Process And Relationship Marketing. British Journal of Management, 12(2), 159-182. Https://Doi.Org/10.1111/1467-8551.00192

Rangkuti, F. (2007). Riset Pemasaran. Jakarta: Gramedia.

Rasheed, F. A., \& Abadi, M. F. (2014). Impact Of Service Quality, Trust And Perceived Value On Customer Loyalty In Malaysia Services Industries. Procedia - Social And Behavioral Sciences, 164, 298-304. Https://Doi.Org/10.1016/J.Sbspro.2014.11.080

Rotter, J. B. (1967). A New Scale For The Measurement Of Interpersonal Trust. Journal Of Personality, 35(4), 651-665. Https://Doi.Org/10.1111/J.1467-6494.1967.Tb01454.X

Schiffman, L., \& Kanuk, L. L. (2007). Consumer Behavior. New Jersey.

Semuel, H., \& Wijaya, N. (2009). Service Quality, Perceive Value, Satisfaction, Trust, Dan Loyalty Pada Pt. Kereta Api Indonesia Menurut Penilaian Pelanggan Surabaya. Jurnal Manajemen Pemasaran, 4 No. 1, 23-37.

Siddiqi, K. O. (2011). Interrelations Between Service Quality Attributes,Customer Satisfaction And Customer Loyalty In The Retail Banking Sector In Bangladesh. International Journal Of Business And Management, 6(3), 12-36.

Sweeney, J., \& Soutar, G. (2001). Consumer Perceived Value: The Development Of A Multiple Item Scale. Journal of Retailing, 77(2), 203-220. Https://Doi.Org/10.1016/S00224359(01)00041-0

Tatuil, A. (2013). The Impact Of Service Quality And Trust To Customer Loyalty Through Customer Satisfaction At Bank BCA Manado. EMBA, 1 No.4, 1182-1188.

Tumini, \& Pratiwi, M. D. (2016). Pengaruh Kualitas Pelayanan Dan Kepercayaan Terhadap Loyalitas Pelanggan Pada Perusahaan Otobus Akas Iv Probolinggo. In Dinamika Global : Rebranding Keunggulan Kompetitif Berbasis Kearifan Lokal (Pp. 286-300). Jember: Prodi Manajemen Fakultas Ekonomi Dan Bisnis Universitas Jember.

Utami, S. S. (2013). Analisis Pengaruh Trust Dan Commitment Terhadap Kepuasan Dan Loyalitas Pelanggan Cv. Sumber Jaya Sakti Tarakan. Jurnal Manajemen Pemasaran, 1 No. $2,1-9$.

Vuuren, T. Van, Lombard, M.-R., \& Tonder, E. (2012). Customer Satisfaction , Trust And Commitment As Predictors Of Customer Loyalty Within An Optometric Practice Environment. Southern African Business Review, 16(3), 81-96.

Woodruff, R. B. (1997). Customer Value: The Next Source For Competitive Advantage. Journal Of The Academy Of Marketing Science, 25(2), 139-153. Https://Doi.Org/10.1007/BF02894350 
Yang, Z., \& Peterson, R. T. (2004). Customer Perceived Value, Satisfaction, And Loyalty: The Role Of Switching Costs. Psychology And Marketing, 21(10), 799-822. Https://Doi.Org/10.1002/Mar.20030

Zeithaml, V. A., \& Bittner, M. . (2003). Services Marketing: Integrating Customer Focus Across The Firm (3rd Editio). New York: The Mcgraw Hill Companies, Inc. 